\title{
Social justice in development studies literature Historical concept analysis
}

\author{
Ingy Mohamed Abdelhameed ${ }^{1}$
}

\begin{abstract}
:
This paper critically analyses the importance of social justice in development studies. In doing so, it raises some questions about the attention that has been given to social justice in development literature since late Forties, especially, How did this affect development policies on both national and international levels? And How all above mentioned were affected by the great international events in more than sixties years? It uses historical conceptual analysis to explore the main changes that social justice as a concept has gone through in development studies and the impact of ideological and political changes on it.
\end{abstract}

\section{Introduction}

Since late Forties, social justice hadn't been the main focus of development studies. The main goal of development-practically and theoretically- had been either achieving economic growth or reducing poverty rates.

In The Sixties, The Dependency theorists claimed that to achieve justice Third World countries need to break the exploitative economic relations with Western economies. This was the first time for Justice to be on the forefront of the development studies. However, The Dependency theory didn't stand the great changes that the world had faced during the debt crisis in early Eighties. As Severine Deneuln said" The Dependency theory was short-lived, and justice disappeared from development studies to make room for pro-poor growth". Not only did justice disappear from development studies, but also from international organizations' discourse on development. Though these organizations have been working on poverty alleviation for many decades, they didn't incorporate justice as a concept or even as a goal in any development strategy. Development was measured by economic growth only, despite the fact that numbers were very delusive because it didn't give any weight to the real living conditions of people. Consequently, The debate on social justice disappeared again from development studies till early Nineties.

During Nineties, justice regained more attention from development theorists and scholars. Amerata Sen and some other scholars like Martha Nussbauim were the pioneers and they gave justice and other liberal values great importance, their interest in Justice and Equality was driven by their emphasis on individual rights and freedoms. Therefore justice for them is not anymore the product of structure relations but the main outcome of relations between individuals. Amartya Sen presented his idea about 
"Development as Freedom" or the capability approach. He has many contributions in integrating justice in development studies, the last but not least of these contributions was his book "The Idea of Justice" which seemed not to have any new arguments but in fact it is considered to be a great contribution by emphasizing on more freedoms as a matter of justice. Amartaya sen and Martha Nusbaum questioned the core interest of development studies and the main target of development policies as well. They argued that the main question of development should have been why do we have inequality and how to reduce it in order to achieve development?, Rather than searching how to reduce poverty and increase economic growth.

According to all the above mentioned, This paper aims at studying social justice as one of the controversial concepts in development studies, using Historical Concept analysis to understand how social justice as a concept in development has been affected by the great changes that development studies has gone through for more than six decades since late Forties?

This paper will go firstly through the current trend in Inequality and Injustice all over the world, then it moves to concept analysis and the main reason for choosing it as the research methodology. Afterwards, it will go through the main changes that social justice has gone through in development studies. It will try to see the different current trends in tackling justice.

\section{Justice and Inequality in current trends:}

For more than ten years now, the world has been under a great wave of protests and social movements against inequality and injustice. From United States to Spain and more importantly The Arab Countries, People around the world went out calling for more social justice programs and real democracy. As there are many evidence from different countries -even very well established democracies- that representative democracy is no longer an effective way for the least privileged to express their needs and to have an influence on policy making. This global trend which will be increasing in the upcoming years has many reasons over and above, is that real social and economic policies are not pro-poor and they represent the interests of the most influential group of people who control got great power even on democratic producers that might affect their interests. Statistics show a decline in international rate of inequality which is a great step, however the national levels had shown great and rapid increase in inequality which is much more important than Inequality between countries. According to Oxfam International the number of people who are controlling the international economy is declining which means more concentration of wealth and influence in the hands of less people than ever before. This will be automatically translated into less poverty oriented programs. As a result many development policies put poverty reduction as their main goal instead of focusing on inequality as the main source of poverty and deprivation.So, These days inequality and social justice became one of the main priorities on the development agenda, not only for policy makers, but also for academics and scholars all over the world. Changes on the ground forced a decisive change in international development way of thinking. Now there are more studies and increasing voices among Human rights activists and international NGOs for the need to change liberal economic 
policies in order to pay more attention to the unprecedented increase in inequality rates. For example, Oxfam International published very invaluable report entitled" Global Wealth is becoming increasing concentrate among small elite" and they circulated its recommendations during Davos 2015. According to this report, in 2014 the richest 1\% of people in the world owned $48 \%$ of the global wealth, leaving just $52 \%$ to be shared between the other $99 \%$. Moreover, $52 \%$ is owned by those included in the richest $20 \%$ of the $99 \%$, leaving only $5.5 \%$ for the remaining $80 \%$ of people in the world. Oxfam warned that if this trend continues in the foreseeable future, the increasing wealth of the richest 1\% will have more wealth than the remaining $99 \%$ in two years. Moreover, the wealth of the richest 80 persons in the world is now the same as $50 \%$ of the global population. Which means that 3.5 billion people share between them the same amount of wealth as extremely 80 people. Furthermore, the number of wealthy people had decreased since 2010 from 388 to 80 billionaires only as an evidence that global inequality trends will be increasing in the near future1. Worth mentioning that the international human development report 2014 talked too about it. The world Human Development Report 2014 entitled "Sustaining, human Development"(1).

\section{Methodology}

\subsection{Conceptual analysis}

As James Farr said" the only constant thing about political concepts is that they are changing all the time" that is why analyzing political concepts is very useful to understand the different meanings of any concept not only through different context but also in the same context over different periods of time. Conceptual analysis has been used by linguistics for many years then political scientist knew it as a new method to understand the meaning of controversial concepts in different context.

The main reason of importing concept analysis from linguistics to political science was to remove ambiguity from political theory, in order to make the used language in political science more meaningful and precise.

As Terrence Ball argued in "Political Theory and Conceptual Change", political theory from Plato to the present is full of misleading persuasive definitions which needs clarification, he said " The only hope for political theory lay in purging its language to make its concepts cognitively meaningful". The main aim of logical positivism was to clarify the language of political theory, in order to refining and redefining the vocabulary of politics. They specified the primary purpose of political theory is to " define the concepts of political science "and presenting accurate and precise definitions for political concepts.

Conceptual History analysis is one phase among many others that concept analysis has gone through. It asks some questions concerning the transformation in the concepts that constitute the political discourse. If we apply this on Social justice we can ask many questions like, How do we identify changes in political discourse of social justice during more than Sixty years? Which concepts related to social Justice had their meaning got 
more attention? How did these changes in Social Justice come about? Who did bring them and for what reasons? And what difference did this make?

Terrence Ball said that" political discourses and the concepts that constituted them have histories that could be narratively reconstructed in many Number of ways. Such histories would show where these discourses functioned and how they changed".

During late Nineties, Terrence Ball added new contribution in historical conceptual analysis, he said that words -in the form of concepts- were the real weapons of any ideology by which it influenced people to believe in it and act according to that believe. However, he believed that not all words had the same effect. So, Any ideology has two types of concepts, one is the core concepts which are both central and constructive for the ideology, like class for Marxism or individual liberty for liberalism. On the other hand, Sore concepts are -according to Ball- core concepts whose meanings are unstable or contested by other ideologies or changes in the whole context like, socio-political, economic or environmental changes. If we apply this idea on Social Justice in Development theory, we will realize that it has gone through many changes, not only in meaning but also in the implications of an adopted definition at a certain point in time (3).

He also added that concepts used in political discourse can't be narrated a part from the political conflicts surrounding them. If we apply this on social justice as a concept in development discourse, we will find that social justice has been subject to ideological and political conflicts all the time. These conflicts were the main reason of its disappearance from the core interest of development studies for decades. Social justice has been going through two parallel levels of change, on ideological level with all the changes of its meaning and significance and on politics level through the change of the framework that dominate development policy making process ( $\left.{ }^{4}\right)$.

Moreover, the debate on social justice in development is not new at least on theoretical level, as Many political philosophers has been talking about it, From John Rawls to Amaratya Sen. Though the world hadn't seen ideological conflict -like it used to be during The Fifties, Sixties and seventies- Development studies were the subject to many changes not only economic but also political ones. All these changes had great effect on Development studies as a whole and social justice as the main concern of it.

Furthermore, There is a strong co-relation between conceptual change and political change and vice versa. As James Farr put it, this understanding must be historical. He argued that political acts are expressed in language and this language is not only the mere verbal expressions, it includes believes, actions and practices of certain agents in history. For example, in his historical speech in 1949 American President Henry Truman used for the first time the concept development when he adopted a plan to help and develop the least developing countries.. That speech was very debatable and there were many interpretation of its content, but the most significant thing about it was the launch of a new area in the relationship between developed countries and developing countries which paved the way to the establishment of many International Development organizations that have been working from the same transcendental way of thinking and policy making. As a result, most of the development strategies were top-down strategies which lacked any contribution from the targeted societies. The very concept of development -back then- meant rapid economic growth, which would be the main weak 
point in Development theory and practice during the Twentieth Century(5).

According to James Farr, political actions prerequisite a shared understanding among political actors on political practices which imply that there is an agreement among main actors on political concepts. If we apply this to the inclusion of social justice in development theory and practice, we will find that there is no such agreement among all the actors to the extent that social justice wasn't at all mentioned on the agenda of either policy makers or development scholars and specialists. The attention that has been paid to social justice was affected by two factors, both of them related to main turning points in History. The first factor, is the ideological changes that the world had gone through during the previous six decades. The second factor is the power relations on international level which impose its main interests on development theory and practice. This point will be discussed in the following part of this paper.

\section{Social Justice as a mere concept in development studies:}

In this part, the paper tries to discuss the relation between social justice and development in development studies. Having said that, social Justice( as a concept) hasn't been mentioned till late Sixties. This part will start from Dependency theory, then classical liberal thoughts of John Rawls, afterwards it will go through the Neoliberal thoughts of Amrateya Sen concerning the relationship between development and social justice and the emergence of The capability approach, it will discuss the PostDevelopment approach as one of the main reactions to the injustices and inequalities the world has been witnessing, as the result of Modernism and the power relations that it has created in an exploitative relation with poor countries.

\section{Justice as fairness: its origins and critique}

Social justice is considered to be one of the controversial concepts not only in development studies but also in political science and political philosophy in general. Though the debate on Social Justice has been on the agenda for ages, John Rawls considered to be one of the most important pioneers in talking about justice as an acceptable philosophical and moral basis for democratic institutions and answers the questions: How the claims of liberty and equity are to be understood?

In his book "Justice as fairness: a Restatement", John Rawls claimed that democratic society can't be considered as a community which means a body of persons united in affirming the same comprehensive doctrine. Instead, Political society according to John Rawls shouldn't be considered as an association because we find ourselves in it, we don't engage in it voluntarily. Political Society is rather a fair system of cooperation arrangements over time which are transferred over time from generation to the next. The main characterization of this society is that those who are engaged in it are equal and free. The main concern for John Rawls was how to generate a political society which guarantee that all citizens who engage in cooperation will be free and equal. He claimed that this might happen by formulating principles of political justice such as political and social institutions and the structure that fit them together as on scheme of cooperation. He also raised some questions about the kind of principles and ideals that such a society 
try to realize given the circumstances of justice in a democratic culture. He argued that the main goal of justice as fairness is to provide an acceptable moral basis for democratic institutions and solve the dilemma of being a liberal society where everyone is equal and free in one hand and achieving justice in the other.

He introduced justice as fairness as the main idea of a fair society and a system of cooperation over time from one generation to the next. Justice as fairness is the main idea and it goes in conjunction with two other principles; 1) citizens are free and equal 2) well-ordered society that is, a society effectively regulated by public acceptance of cooperation. According to Rawls, The organizing idea of social cooperation has at least three essential features: 1) social cooperation is distinct from merely socially coordinated activity, 2) The idea of cooperation includes the idea of fair terms of cooperation, 3) the idea of cooperation includes the idea of participant rational advantage or good. ${ }^{2}$ The main goal of the idea of justice as fairness is to find a way to resolve the problem of opposing personal interests in a free and equal society, Justice as fairness is considered to be the reasonable base for a political concept of justice upon which people decide how to cooperate with each other without having to surrender their freedom and liberty $(7)$.

According to Rawls, fairness aims at reaching set of principles that the society can depend on while establishing just institutions. He specified some principles to establish just institutions which are chosen by people in the original position. In the original position people are equal and they impartially chose among many options the most proper for the society. They are impartial because they have what he called "veil of ignorance". The process of choosing just Institutions depends on two principles, 1) all people in the political society are equal. 2) Any sort of social or economic inequality are permitted at two conditions, first it has to be based on open social conditions for everyone, second, any sort of violation of the previously mentioned principles should be for the good of the least privileged in society.

Though Justice as fairness was the milestone in liberal theory, his ideas on social justice have been a subject of criticism from many scholars. Some of these criticisms were related to development studies. The most controversial ones were the Post-development approach and the Capability approach and "The idea of justice" which Amartya Sen has introduced later in 2009.

These two approaches are by far contradicting each other in introducing a different way of thinking about how to incorporate social justice in development policies and studies. These two approaches appeared during Nineties as reaction to the failure of social and economic development policies in different regions of the world. Not to mention that, both approaches are the reflection of a great shift from the nation state as the main actor in development to individuals not only as main actors in development policies but also as the end target of it and the well-being of people substituted the economic growth and poverty reduction(8).

\section{Neo-liberal approach to Social Justice}

The leading contributor in this approach is The Nobile prize winner Amaratya 
Sen, he was working on a new approach in development based on Liberal theory but focusing more on human well-being. In his book "Development as Freedom" he argued that development is not equal to economic growth or wealth accumulation, it is mainly related to peoples' freedom to choose among many different options to live the life they acclaim. Based on this assumption, he established his leading approach in development theory and practice which is Capability Approach or Human Development approach $^{3}$.

In 2009, he published another book entitled "The idea of justice" which was considered by many scholars as another breakthrough in development theory. In this book he tried to criticized mainstream liberal thoughts on justice, he tried to draw more comprehensive and comparable view for the relationship between social justice and development in the light of his previous work on development as freedom. He started his argument about the relationship between development and social justice in Neo liberal theory. In his book Amartaya Sen started his argument by question the way his predecessors had asked about justice.

According to Sen, political theorists don't need to ask what is justice? Instead, they need to have a common agreement on what is unjust and what are the proper ways to correct injustice. In order to achieve this, we need to compare between different situations to achieve a relevant agreement on what is considered to be justice and how to eliminate injustice. The deliberation on the main features of injustice and how to face it, usually happens through "public reasoning" which is a democratic process through which people cooperatively choose between different combinations of alternatives. He claimed that public reasoning might end up changing some people believes and attitude towards unjust situations. He agreed with John Rawls on giving personal freedom and liberty the priority, but he disagreed with him on overrating the importance of institutions as a priority in achieving justice. He disagreed with him on many things specially "The veil of ignorance" as a hypothetical position in which people don't know anything about their vested interests, so they partially and rationally choose the main principles of justice as the corner stone for the establishment of just institutions as the core of the political society. For Sen, this is unrealistic and can't be achieved on the ground, because we have different and conflicting interests. Sen doesn't give any weight to the institutional arrangements, he concentrates more on individuals per se and the way they are capable of practicing their freedom to choose the life they would like to live and how far they are able to practice their basic rights and entitlements in society.

Moreover, he emphasized that social justice will not be achieved by a just dictator, the only proper setting to achieve social justice is through democratic process in which each person has the full capability to express his thoughts and practice his freedom of speech without any coercion from the authority. He admits that there is no complete agreement among different people. So, we need to reach a relevant agreement not an absolute one, because this sort of agreement is unachievable. Not only did he deny any affirmation of his approach, he also claimed that this approach is informative and it doesn't give any suggestion to remove injustice.

Given the fact that his work was a great break through, however there are many critics to 
the quasi ideal model he has presented. Some of the critical see contradiction between his critics to what he called " The transcendental institutional approach" and theoretical framework for his approach(10).

\section{The Capability Approach revisited (Martha Nussbiam view)}

On the other hand and within the same approach, Marth Nusibam a feminist professor and activist, tried to introduce another and more in depth contribution to this approach. She admits that Sen's attempt to tie social justice and development through his manifestation on freedoms was a breakthrough. However, He didn't present a comprehensive frame of the main or the threshold capabilities that any society needs to protect for its people. She defined capability as" the freedom to choose among many alternatives, the one you want most." Based on this definition she divided capabilities into three categories, 1) Internal Capabilities which are the main capabilities that anyone personally can have in the society like education, wealth and etc 2) Combined Capabilities, they present the internal capabilities plus the political, social and economic conditions in the society 3) Basic or central capabilities are the capabilities that any society should guarantee for all citizens fairly and equally.

Consequently, she introduced a list of ten main central capabilities as a threshold for any society to be considered just and fair. She tried in this list to combine many basic freedoms and entitlements that there present is a must for any society that is trying to have the minimal level of social justice.

This list includes basic capabilities that can't be left to social dynamics and needs preaffirmation from the government, such as ${ }^{4}$;

-Life: Being able to live to the end of a human life of normal length; not dying prematurely.

- Practical reason. Being able to form a conception of the good and to engage in critical reflection about the planning of one's life.

- Affiliation. (A) Being able to live with and toward others, to recognize and show concern for other human being to engage in various forms of social interaction; to be able to imagine the situation of another. B) Having the social bases of self-respect and non-humiliation: being able to be tr4eated as a dignified being whose worth is equal to the others. This entails provision of nondiscrimination on the basis of race, sexual orientation, ethnicity, caste, religion, or national origins.

- Control over one's environment: A) Political. Being able to participate effectively in political choices that govern one's life; having the right of political participation, protection, protections of free speech and association. B) Material. Being able to hold property, and having property rights on an equal basis with others, having the right to seek employment on an equal basis with others, having the freedom from unwarranted search and seizure. In work, being able to work as human being, exercising practical reason and entering into meaningful relationships of mutual recognition with other workers. 


\section{Post-Development approach: A radical view}

This approach is considered to be the most radical approach in development studies. Not only, did they refused all development theories, but also they announced the end of development as a way to guarantee the continuity of the exploitative relation between the most powerful societies and the weak ones. Consequently, They refuse development policies all together as they didn't present any solutions to get people out of their misery. They criticized dependency theory as well for "The third world" concept as they didn't pay any attention to the great differences among the so called" third world countries." According to this approach all development theories -even Dependency theory- failed to take into consideration the diversity not only between different societies but also in the same society among different groups.

The main contribution of this approach is a book entitled" The development Dictionary: A guide to knowledge as power" this book gathered most of the main contributions of this approach which tried to deconstruct most of the well-known concepts that has been adopted by Modern theory like state, poverty and Development. One of the main critics to this approach that it is to deconstructive to the extent that its theorists had no time to build a solid alternative to the already existing theory and practice ${ }^{5}$.

\section{Conclusion}

Finally, we can say that social justice wasn't the really target of neither the theory nor the practice of development for many decades. However, There are many factors that paved the way for it to regain its importance, the first and foremost is the increasing inequality gap not only within one country but also, among countries, plus the effect of globalization that made the whole world face the inequality gap effects

Moreover, The previous review of the main shifts in the conceptual history of social justice in development studies implies that social justice as a concept and policy target has been facing many changes according to the political, ideological, economic conditions not only on the national level, but also and more importantly the international ones. Not to mention that, the international power conflicts have great influence on the issues that not only development literature discuss, but also and more importantly on international development agenda which made the issue of social justice not a matter of importance. As Amaratya Sen referred in his book " The Idea of Justice" why all the development strategies have emphasized on poverty alleviation as the main concern and target of development policies. Policy makers should rather focus on reducing inequality as the main cause of poverty.

Though the international community have been revising its development policies and discourse to incorporate justice issues like environmental sustainability and gender equality, they are still lagging behind concerning social policies that might help impoverished people to get out the poverty circle and get better opportunities to life the life they are looking up for. Thus, Social justice as a concern for development needs to be revisited. 


\section{References:}

1. Jan Nederveen, Pieterse, The development of development theory: Towards Critical globalism, Review of international political economy, Vol.3, No.4 (Winter.1996), pp541-564

2. Frans, J, Schuurman, Paradigms lost, paradigms regained? Development studies in the twenty-first century, Third World Quarterly,Vol.21,No.1,pp7-20,2000

3. Jams,Farr, Understanding conceptual change politically,----

4.Terrence, Ball, Political Theory and Conceptual Change,

5. Wolfgang Sachs(Editor),The Development Dictionary a guide to knowledge as power, Second Edition, Zed Books, London \&New York,2010,ppVI-VXI.

6. John, Rawls, Political liberalism, expanded edition, Columbia Classics in philosophy, Columbia University Press, 2005

7. John, Rawls, A theory of Justice, original edition, U.S.A, 1971

8. Amartya, Sen, Development as freedom, NYC, U.S.A, 2000

9. Amartya, Sen, The Idea of Justice, Penguin Books, London, UK, 2009

10. Martha C. Nussbaum, Creating capabilities, the human development approach, The Belknap Press of Harvard University Press, U.S.A, 2011pp15-17

11. Martha, C. Nussbaum, Frontiers of Justice, Disability, Nationality, species membership, Harvard University Press, U.S.A, 20000

12. Arturo, Escobar, Encountering Development: The Making and Unmaking of the third world, Princeton University Press, U.S.A, 1995 